\title{
Popularity and impact of using smart devices in medicine: experiences in Saudi Arabia
}

\author{
Sameer Al-Ghamdi(D)
}

\begin{abstract}
Background: The present study aimed to investigate smart device medical apps currently preferred by physicians in Saudi Arabia and the perceived impact of the apps on patient care.

Methods: Questionnaires for this cross-sectional study on smart device medical apps were randomly emailed to 384 physicians registered in the Saudi Commission of Health Specialists database. A total of 300 physicians returned completed questionnaires, with a response rate of 78.5\%. Physician demographics and their perceptions of medical apps were assessed, including questions on the purpose, impact, and types of medical apps used. Questions were answered using a Likert scale ( 1 = strongly disagree, $2=$ disagree, $3=$ not sure, $4=$ agree, and $5=$ strongly agree).
\end{abstract}

Results: Study subjects had a median age of 39 years (57.7\% male). Most respondents (88.3\%) had smart devices, and $86.3 \%$ had at least one medical app installed. Just over half used an app at least once a day (53.0\%). Medical apps were positively perceived, with physicians reporting increased dependency on the apps (Likert score: $4.7 \pm 0.5$ ).

Conclusion: Medical apps were perceived to positively impact education, physician efficiency, and patient care.

Keywords: Smartphone, Smart device, Medicine, Saudi Arabia

\section{Background}

The use of smart device applications (apps) in the medical setting has been steadily increasing in recent years $[1,2]$. This is generally beneficial because smart device medical app use has been shown to increase physician productivity [1-4], efficiency [3, 5-7], and accuracy $[3,6,8,9]$ and to improve patient access to medical care $[3,10]$. However, medical apps have received both positive and negative reviews from practicing physicians [10]. Therefore, identifying the best app was important. Medscape, UpToDate, Lexicomp, and Epocrates have received positive ratings and are most commonly used by healthcare workers [11]. In contrast, other applications were poorly rated because of low performance that did not meet healthcare workers' needs. Some issues raised include app reliability [12, 13] and diagnostic accuracy [12-17], along with patient health disparities and poor health knowledge [18].

Correspondence: Sam3443@gmail.com

Department of Family Medicine, College of Medicine, Prince Sattam bin Abdulaziz University, Al Kharj, Saudi Arabia
Smart phone medical apps are considered a major improvement to medicine, particularly in heavily populated countries [1, 3], which can be socioeconomically diverse. Saudi Arabia's population is also socioeconomically diverse and many people cannot afford medical insurance or to pay for their medical care directly. Because medical apps improve physician efficiency $[3,5,6]$ and productivity [1-4], they may help reduce hospital congestion, improve access to medical care, and reduce medical care costs. Therefore, it is important to understand how medical apps can improve patient healthcare and which apps will be most useful to specific healthcare systems. Here, we examine current physician use of smart device medical apps in Saudi Arabia and their perceived impact on patient care.

\section{Methods \\ Sample and procedures \\ All data were collected using an anonymous questionnaire based on a previously published study [19]. Names of po- tential study participants were obtained from the Saudi Commission of Health Specialties database. Physicians were}

(c) The Author(s). 2018 Open Access This article is distributed under the terms of the Creative Commons Attribution 4.0 International License (http://creativecommons.org/licenses/by/4.0/), which permits unrestricted use, distribution, and reproduction in any medium, provided you give appropriate credit to the original author(s) and the source, provide a link to the Creative Commons license, and indicate if changes were made. The Creative Commons Public Domain Dedication waiver (http://creativecommons.org/publicdomain/zero/1.0/) applies to the data made available in this article, unless otherwise stated. 
randomly selected using a simple random sampling method implemented with a computer random number generator. Invitations to participate in the study were sent by email to the addresses in the database.

In order to ensure that the sample was highly representative of the study population, the sample size was calculated according to the following formula (OpenEpi 2017): $n=\left[\operatorname{DEFF}^{*} \mathrm{~Np}(1-\mathrm{p})\right] /\left[\left(\mathrm{d}^{2} / \mathrm{Z}^{2}{ }_{1-\alpha / 2}{ }^{*}(\mathrm{~N}-1)+\mathrm{p}^{*}(1-\mathrm{p})\right]\right.$, where $\mathrm{n}=$ the calculated sample size, $\mathrm{N}=$ the total study population size $(86,756$ physicians [20]), DEFF $=$ design effect (for cluster surveys, $1 \%$ ), $\mathrm{p}=$ hypothesized \%frequency of the outcome factor in the population (considered to be $50 \%$ ), and $d=$ the confidence limits as \pm percent of 100 (5\%). According to this formula, the sample size was calculated to be 382 . Invitations to participate in the study were sent to 384 medical practitioners. A total of 300 physicians returned completed questionnaires, with a response rate of $78.5 \%$.

The study questionnaire consisted of several parts. Part 1 collected participants' demographic data, including age, gender, whether or not a mobile device was used, whether or not medical apps were installed on a smart device, the purpose of installed medical apps, and whether or not their hospital/institute recommended specific medical apps. Part 2 assessed the participants' perception of smart device medical apps. Part 3 assessed the impact of medical apps on clinical training and practice. Part 4 evaluated what medical apps were used. Responses to questions in parts $2-4$ were based on a 5 -point Likert scale: $1=$ strongly disagree, $2=$ disagree, $3=$ not sure, $4=$ agree, and $5=$ strongly agree . Questionnaires that were only partially completed were not included in the analysis (Additional file 1).

\section{Inclusion criteria}

Being a licensed physician registered in the Saudi Commission of Health Specialties database and willing to participate in the study were the inclusion criteria of the study, and the questionnaire was in English.

\section{Statistical analysis}

Data were analyzed using SPSS statistical software (version 21, SPSS, Inc., Chicago, IL, USA). Subject characteristics are presented as frequencies (percentage). Quantitative Likert scale data are presented as mean \pm standard deviation.

\section{Ethical considerations}

This prospective, cross-sectional study was reviewed and approved by the Deanship of Scientific Research at Prince Sattam bin Abdulaziz University (No. 2017/03/3361). The study did not involve any medical examination, surgical procedure, or collection of personal health information. Therefore, completing and returning the questionnaire was considered as provision of informed consent to participate in the study. The study was conducted in adherence to the tenets of the Declaration of Helsinki.

\section{Results}

Demographic characteristics of and smart device use by physicians in Saudi Arabia

Study subjects had a median age of 39 years (range: 2667 years), and $57.7 \%$ subjects were male. Additionally, $43.0 \%$ of subjects were resident medical physicians, $33 \%$ were registrars, $12.3 \%$ were senior registrars, and $11.7 \%$ were consultants.

Approximately $88.3 \%$ of subjects used smart devices. All participants were aware that medical apps are available for smart devices and $86.3 \%$ had medical apps installed on their smart devices. Additionally, $88 \%$ of subjects reported that their hospital/institute recommended a specific medical app for their device. Participants reported using installed medical apps at least once a day $(53.0 \%)$, at least once a week (35.3\%), or less than once per month (11.7\%, Table 1).

\section{Purpose of using installed smart device medical apps and} frequency of use of installed medical apps

Installed smart phone medical apps were most commonly used for revision of medical knowledge (82.3\%), for presentation preparation $(75.3 \%)$, during ward rounds $(71 \%)$, for medical information look-up (70\%), for medical news updates (70\%), for clinical skills guidance (69.7\%), and for medical journal viewing (68.7\%). Other usages included viewing of medication and drug guides (65\%), preparing for exams (65.7\%), and viewing of general clinical textbooks (53.3\%). Approximately $12 \%$ of medical practitioners reported that they did not have a medical app installed (Table 2).

Table 1 Demographic characteristics of and smart device use by physicians in Saudi Arabia ( $n=300$ subjects)

\begin{tabular}{|c|c|c|c|}
\hline & & Number & Percent \\
\hline \multirow[t]{2}{*}{ Gender } & Male & 173 & 57.7 \\
\hline & Female & 127 & 42.3 \\
\hline \multirow[t]{4}{*}{ Medical rank } & Resident & 129 & 43.0 \\
\hline & Registrar & 99 & 33.0 \\
\hline & Senior registrar & 37 & 12.3 \\
\hline & Consultant & 35 & 11.7 \\
\hline \multirow[t]{2}{*}{ Are you using smart devices? } & No & 35 & 11.7 \\
\hline & Yes & 265 & 88.3 \\
\hline $\begin{array}{l}\text { Are you aware of the availability } \\
\text { of medical apps on smart devices? }\end{array}$ & Yes & 300 & 100.0 \\
\hline \multirow{2}{*}{$\begin{array}{l}\text { Have you installed medical apps } \\
\text { on your smart device? }\end{array}$} & No & 41 & 13.7 \\
\hline & Yes & 259 & 86.3 \\
\hline \multirow{2}{*}{$\begin{array}{l}\text { Has your hospital/institution ever } \\
\text { recommended that you obtain } \\
\text { a specific medical app for your } \\
\text { mobile phone? }\end{array}$} & No & 36 & 12.0 \\
\hline & Yes & 264 & 88.0 \\
\hline \multirow{3}{*}{$\begin{array}{l}\text { Frequency of use of installed } \\
\text { medical apps }\end{array}$} & zonce/day & 159 & 53.0 \\
\hline & zonce/week & 106 & 35.3 \\
\hline & sonce/month & 35 & 11.7 \\
\hline
\end{tabular}


Table 2 Purpose for using installed smart device medical apps ( $n=300$ physicians)

\begin{tabular}{lll}
\hline & Number & Percent \\
\hline Reviewing medical knowledge & 247 & 82.3 \\
Preparing presentations & 226 & 75.3 \\
During ward rounds & 213 & 71.0 \\
Reading medical news & 210 & 70.0 \\
Looking up medical information & 210 & 70.0 \\
Clinical skills guide & 209 & 69.7 \\
Reading medical journals & 206 & 68.7 \\
Exam preparation & 197 & 65.7 \\
Medication or drug guide & 195 & 65.0 \\
General clinical textbook & 160 & 53.3 \\
I do not have medical apps & 36 & 12.0 \\
\hline
\end{tabular}

Female medical practitioners at junior, registrar, or below ranks used installed medical apps at least daily or once a week compared with their counterparts with chi-square $=47.265, p<0.001$; age with the chisquare $=318.273, p<0.001$; and medical rank with the chi-square $=374.4, p<0.001$, respectively, as shown in Table 3.

The majority of medical practitioners agreed or strongly agreed that medical apps are easy to obtain (mean Likert score $=4.8 \pm 0.4$ ); they are looking to obtain more medical apps in the future $(4.7 \pm 0.5)$; they would recommend using medical apps to other medical practitioners $(4.7 \pm 0.5)$; they do most of their medical learning using medical apps $(4.3 \pm 1.0)$; medical apps are essential tools for undergraduate medical students $(4.7 \pm 0.5)$; and medical apps are superior to medical textbooks $(4.3 \pm 0.8)$. Practitioners also favored medical apps by saying that they are as good as medical books $(4.7 \pm 0.5)$; medical apps can replace medical books $(4.7 \pm 0.5)$; medical apps supplement medical books (4.6 \pm 0.7$)$; medical apps provide useful point-of-care medical information (4.8 \pm 0.52$)$; and medical apps use is not dangerous for patient care $(4.6 \pm 0.6)$.

\section{Perceptions of smart device medical apps and its impact on clinical practice}

The majority of providers disagreed with or were not sure if medical apps are inferior to medical textbooks $(3.1 \pm 1.7)$. The same was true regarding whether free medical apps are inferior in quality to paid apps $(3.2 \pm 1.7$, Table 4$)$.

A majority of medical practitioners agreed or strongly agreed that medical apps improve clinical decision making $(4.7 \pm 0.6)$, save time $(4.3 \pm 1.1)$, allow for faster access to national clinical practice guidelines $(4.3 \pm 1.1)$, allow for faster access to common laboratory reference values $(4.7 \pm 0.5)$, help in making differential diagnoses $(3.9 \pm 1.3)$, and perform useful medical-related calculations (e.g., estimate creatinine levels; $4.5 \pm 0.7$ ). Additionally, medical apps were thought to be beneficial for allowing faster access to reliable medical knowledge sources $(4.8 \pm 0.4)$, faster access to reliable clinical skill sources $(4.8 \pm 0.4)$, more accurate medication dosing calculations $(4.4 \pm 1.0)$, easier medication dosage calculations $(4.6 \pm 0.7)$, and faster access to evidence-based medical practices $(4.7 \pm 0.7$, Table 5$)$.

\section{Medical apps commonly used}

The medical apps most commonly used by medical practitioners were as follows: Medscape (79\%), Oxford medical dictionary (74.3\%), Skyscape (69.3\%), UpToDate (64.7\%), Gray's Anatomy (63.3\%), Epocrates (62.7\%), Student BMJ (60.7\%), Oxford clinical handbooks (59.3\%), Prognosis (57\%), and iPharmacy (51.3\%). Other medical applications commonly used included Pubmed mobile (48.3\%), Differential Diagnosis BMJ (38\%), Pocket lab values (30\%), ECG guide (30.7\%), iStethoscope (29.3\%),

Table 3 Gender and medical rank with the frequency of use of installed medical apps

\begin{tabular}{|c|c|c|c|c|c|c|c|c|}
\hline & & \multicolumn{3}{|c|}{ Frequency of use of installed medical apps } & \multirow[t]{2}{*}{ Total } & \multirow{2}{*}{$\begin{array}{l}\text { Chi-square } \\
\text { test }\end{array}$} & \multirow[t]{2}{*}{ df } & \multirow[t]{2}{*}{$p$-value } \\
\hline & & $\begin{array}{l}\text { At least } \\
\text { once a day }\end{array}$ & $\begin{array}{l}\text { At least } \\
\text { once a week }\end{array}$ & $\begin{array}{l}\text { Less than } \\
\text { once a month }\end{array}$ & & & & \\
\hline \multirow[t]{2}{*}{ Gender } & Male & 66 & 72 & 35 & 173 & 47.265 & 2 & .000 \\
\hline & Female & 93 & 34 & 0 & 127 & & & \\
\hline \multirow[t]{4}{*}{ Medical rank } & Resident & 94 & 35 & 0 & 129 & 374.400 & 6 & .000 \\
\hline & Registrar & 65 & 34 & 0 & 99 & & & \\
\hline & Senior registrar & 0 & 37 & 0 & 37 & & & \\
\hline & Consultant & 0 & 0 & 35 & 35 & & & \\
\hline \multirow[t]{4}{*}{ Age } & $<30$ years & 51 & 1 & 0 & 52 & 318.273 & 6 & .000 \\
\hline & 30-39 years & 42 & 35 & 1 & 78 & & & \\
\hline & 40-49 years & 64 & 70 & 0 & 134 & & & \\
\hline & $>50$ years & 2 & 0 & 34 & 36 & & & \\
\hline Total & & 159 & 106 & 35 & 300 & & & \\
\hline
\end{tabular}


Table 4 Physicians' perceptions of smart device medical apps

\begin{tabular}{|c|c|c|c|c|c|}
\hline & & Frequency & Percent & Mean & SD \\
\hline \multirow{2}{*}{$\begin{array}{l}\text { Medical apps are } \\
\text { easy to obtain }\end{array}$} & Agree & 300 & 100 & 4.79 & 0.408 \\
\hline & $\begin{array}{l}\text { Strongly } \\
\text { agree }\end{array}$ & & & & \\
\hline \multirow{2}{*}{$\begin{array}{l}\text { I am looking to } \\
\text { obtain more } \\
\text { medical apps in } \\
\text { the future }\end{array}$} & Agree & 102 & 34.0 & 4.66 & 0.475 \\
\hline & $\begin{array}{l}\text { Strongly } \\
\text { agree }\end{array}$ & 198 & 66.0 & & \\
\hline \multirow{3}{*}{$\begin{array}{l}\text { I would recommend } \\
\text { the use of medical } \\
\text { apps to other medical } \\
\text { practitioners }\end{array}$} & Disagree & 3 & 1.0 & 4.73 & 0.506 \\
\hline & Agree & 71 & 23.7 & & \\
\hline & $\begin{array}{l}\text { Strongly } \\
\text { agree }\end{array}$ & 226 & 75.3 & & \\
\hline \multirow{3}{*}{$\begin{array}{l}\text { I do most of my } \\
\text { medical learning } \\
\text { using medical apps }\end{array}$} & Disagree & 34 & 11.3 & 4.32 & 0.950 \\
\hline & Agree & 101 & 33.7 & & \\
\hline & $\begin{array}{l}\text { Strongly } \\
\text { agree }\end{array}$ & 165 & 55.0 & & \\
\hline \multirow{3}{*}{$\begin{array}{l}\text { Medical apps are } \\
\text { essential tools for } \\
\text { undergraduate } \\
\text { medical studies }\end{array}$} & Disagree & 3 & 1.0 & 4.73 & 0.506 \\
\hline & Agree & 71 & 23.7 & & \\
\hline & $\begin{array}{l}\text { Strongly } \\
\text { agree }\end{array}$ & 226 & 75.3 & & \\
\hline \multirow{3}{*}{$\begin{array}{l}\text { Medical apps are } \\
\text { superior to medical } \\
\text { textbooks }\end{array}$} & Not sure & 66 & 22.0 & 4.33 & 0.814 \\
\hline & Agree & 69 & 23.0 & & \\
\hline & $\begin{array}{l}\text { Strongly } \\
\text { agree }\end{array}$ & 165 & 55.0 & & \\
\hline \multirow{2}{*}{$\begin{array}{l}\text { Medical apps are as } \\
\text { good as medical } \\
\text { textbooks }\end{array}$} & Agree & 101 & 33.7 & 4.66 & 0.473 \\
\hline & $\begin{array}{l}\text { Strongly } \\
\text { agree }\end{array}$ & 199 & 66.3 & & \\
\hline \multirow{4}{*}{$\begin{array}{l}\text { Medical apps are } \\
\text { inferior to medical } \\
\text { textbooks }\end{array}$} & $\begin{array}{l}\text { Strongly } \\
\text { disagree }\end{array}$ & 69 & 23.0 & 3.13 & 1.673 \\
\hline & Disagree & 70 & 23.3 & & \\
\hline & Not sure & 37 & 12.3 & & \\
\hline & $\begin{array}{l}\text { Strongly } \\
\text { agree }\end{array}$ & 124 & 41.3 & & \\
\hline \multirow{2}{*}{$\begin{array}{l}\text { Medical apps can } \\
\text { replace medical } \\
\text { textbooks }\end{array}$} & Agree & 101 & 33.7 & 4.66 & 0.473 \\
\hline & $\begin{array}{l}\text { Strongly } \\
\text { agree }\end{array}$ & 199 & 66.3 & & \\
\hline \multirow{3}{*}{$\begin{array}{l}\text { Medical apps } \\
\text { supplement } \\
\text { medical textbooks }\end{array}$} & Not sure & 34 & 11.3 & 4.56 & 0.689 \\
\hline & Agree & 64 & 21.3 & & \\
\hline & $\begin{array}{l}\text { Strongly } \\
\text { agree }\end{array}$ & 202 & 67.3 & & \\
\hline \multirow{3}{*}{$\begin{array}{l}\text { Medical apps provide } \\
\text { useful point-of-care } \\
\text { medical information }\end{array}$} & Disagree & 4 & 1.3 & 4.75 & 0.518 \\
\hline & Agree & 63 & 21.0 & & \\
\hline & $\begin{array}{l}\text { Strongly } \\
\text { agree }\end{array}$ & 233 & 77.7 & & \\
\hline \multirow{4}{*}{$\begin{array}{l}\text { Free medical apps are } \\
\text { inferior in quality to } \\
\text { paid apps }\end{array}$} & $\begin{array}{l}\text { Strongly } \\
\text { disagree }\end{array}$ & 66 & 22.0 & 3.18 & 1.677 \\
\hline & Disagree & 71 & 23.7 & & \\
\hline & Not sure & 34 & 11.3 & & \\
\hline & $\begin{array}{l}\text { Strongly } \\
\text { agree }\end{array}$ & 129 & 43.0 & & \\
\hline
\end{tabular}

Table 4 Physicians' perceptions of smart device medical apps (Continued)

\begin{tabular}{llllll}
\hline & & Frequency & Percent & Mean & SD \\
\hline $\begin{array}{l}\text { There are no } \\
\text { dangers in using }\end{array}$ & Disagree & 8 & 2.7 & 4.60 & 0.634 \\
$\begin{array}{l}\text { medical apps } \\
\text { for patient care }\end{array}$ & Agree & 97 & 32.3 & & \\
& $\begin{array}{l}\text { Strongly } \\
\text { agree }\end{array}$ & 195 & 65.0 & & \\
& Total & 300 & 100.0 & & \\
\hline
\end{tabular}

Micromedex (28\%), Eponyms (23\%), NEJM (13\%), MedCalc (14\%), Instant ECG (12\%), and Diagnosaurus DDx (12\%, Table 6).

\section{Discussion}

This study examined the use and perceived impact of smart device medical apps in Saudi Arabia. In agreement with studies in other parts of the world $[1,5,7,21]$, we found that medical apps are generally well perceived and are reported by care providers to improve efficiency, accuracy, and education in the clinical setting. The medical apps that are most relied upon in Saudi Arabia (63.3\%-79.0\% use) were Medscape, Gray's Anatomy, UpToDate, and Oxford mobile dictionary. These apps were designed to provide medical definitions, review anatomy, and assist clinicians by providing evidencebased answers to clinical questions. This was similar to trends in the United Kingdom, where $86.2 \%$ of surgeons reported using medical apps to access online medical resources $[22,23]$. These findings indicate that Saudi Arabian physicians believe that medical app use directly improves patient care.

Medical practitioners in Saudi Arabia also agreed or strongly agreed that medical apps are important for medical educations of students, resident physicians, and more experienced practitioners. This is in agreement with several studies that examined the use of medical apps specifically designed for resident training [1, 3, 24-26], continuing medical education $[1,3]$, and textbook access $[1,3]$. Additionally, fast access to medical information was the number one benefit of medical apps reported by students [27], residents [28], and practicing physicians [27]. Resident physicians also commonly use apps to perform medical calculations [28].

The study found that hospitals are also recommending the usage of the medical applications. The finding is similar to Lewis and Wyatt $[17,29]$ who reported that hospitals are looking for solutions that will aid efficiency both the clinical care and research. The implication of the hospitals recommending use of medical apps is that will increase access to patient records since there are limited desktops at the health care facilities. [30] The study found that there is a significant difference between gender, age, medical rank and frequency of use of 
Table 5 Perceived impact of smart device medical apps on clinical practice

\begin{tabular}{|c|c|c|c|c|c|}
\hline & & Frequency & Percent & Mean & SD \\
\hline \multirow{3}{*}{$\begin{array}{l}\text { Improve clinical } \\
\text { decision-making }\end{array}$} & Disagree & 8 & 2.7 & \multirow[t]{3}{*}{4.70} & \multirow[t]{3}{*}{0.608} \\
\hline & Agree & 65 & 21.7 & & \\
\hline & $\begin{array}{l}\text { Strongly } \\
\text { agree }\end{array}$ & 227 & 75.7 & & \\
\hline \multirow[t]{4}{*}{ Save time } & Disagree & 42 & 14.0 & \multirow[t]{4}{*}{4.26} & \multirow[t]{4}{*}{1.123} \\
\hline & Not sure & 34 & 11.3 & & \\
\hline & Agree & 29 & 9.7 & & \\
\hline & $\begin{array}{l}\text { Strongly } \\
\text { agree }\end{array}$ & 195 & 65.0 & & \\
\hline \multirow{4}{*}{$\begin{array}{l}\text { Allow faster access } \\
\text { to national clinical } \\
\text { practice guidelines }\end{array}$} & Disagree & 41 & 13.7 & \multirow[t]{4}{*}{4.28} & \multirow[t]{4}{*}{1.106} \\
\hline & Not sure & 30 & 10.0 & & \\
\hline & Agree & 34 & 11.3 & & \\
\hline & $\begin{array}{l}\text { Strongly } \\
\text { agree }\end{array}$ & 195 & 65.0 & & \\
\hline \multirow{3}{*}{$\begin{array}{l}\text { Allow faster access } \\
\text { to common laboratory } \\
\text { reference values }\end{array}$} & Disagree & 5 & 1.7 & \multirow[t]{3}{*}{4.74} & \multirow[t]{3}{*}{0.543} \\
\hline & Agree & 64 & 21.3 & & \\
\hline & $\begin{array}{l}\text { Strongly } \\
\text { agree }\end{array}$ & 231 & 77.0 & & \\
\hline \multirow{3}{*}{$\begin{array}{l}\text { Help in developing } \\
\text { differential diagnoses }\end{array}$} & Disagree & 71 & 23.7 & \multirow[t]{3}{*}{3.86} & \multirow[t]{3}{*}{1.302} \\
\hline & Not sure & 65 & 21.7 & & \\
\hline & $\begin{array}{l}\text { Strongly } \\
\text { agree }\end{array}$ & 164 & 54.7 & & \\
\hline \multirow{3}{*}{$\begin{array}{l}\text { Perform useful } \\
\text { medical related } \\
\text { calculations }\end{array}$} & Not sure & 37 & 12.3 & \multirow[t]{3}{*}{4.52} & \multirow[t]{3}{*}{0.706} \\
\hline & Agree & 69 & 23.0 & & \\
\hline & $\begin{array}{l}\text { Strongly } \\
\text { agree }\end{array}$ & 194 & 64.7 & & \\
\hline \multirow{2}{*}{$\begin{array}{l}\text { Allow faster access } \\
\text { to reliable sources of } \\
\text { medical knowledge }\end{array}$} & Agree & 71 & 23.7 & \multirow[t]{2}{*}{4.76} & \multirow[t]{2}{*}{0.426} \\
\hline & $\begin{array}{l}\text { Strongly } \\
\text { agree }\end{array}$ & 229 & 76.3 & & \\
\hline \multirow{2}{*}{$\begin{array}{l}\text { Allow faster access to } \\
\text { reliable sources of } \\
\text { clinical skills }\end{array}$} & Agree & 71 & 23.7 & \multirow[t]{2}{*}{4.76} & \multirow[t]{2}{*}{0.426} \\
\hline & $\begin{array}{l}\text { Strongly } \\
\text { agree }\end{array}$ & 229 & 76.3 & & \\
\hline \multirow{3}{*}{$\begin{array}{l}\text { Allow accurate } \\
\text { calculation of } \\
\text { medication dose }\end{array}$} & Disagree & 37 & 12.3 & \multirow[t]{3}{*}{4.42} & \multirow[t]{3}{*}{0.993} \\
\hline & Agree & 64 & 21.3 & & \\
\hline & $\begin{array}{l}\text { Strongly } \\
\text { agree }\end{array}$ & 199 & 66.3 & & \\
\hline \multirow{3}{*}{$\begin{array}{l}\text { Allow easier calculation } \\
\text { of medication dose }\end{array}$} & Not sure & 29 & 9.7 & \multirow[t]{3}{*}{4.58} & 0.662 \\
\hline & Agree & 68 & 22.7 & & \\
\hline & $\begin{array}{l}\text { Strongly } \\
\text { agree }\end{array}$ & 203 & 67.7 & & \\
\hline Allow faster access & Not sure & 34 & 11.3 & 4.66 & 0.673 \\
\hline medical practice & Agree & 34 & 11.3 & & \\
\hline & $\begin{array}{l}\text { Strongly } \\
\text { agree }\end{array}$ & 232 & 77.3 & & \\
\hline & Total & 300 & 100.0 & & \\
\hline
\end{tabular}

Table 6 Medical apps used by physicians $(n=300)$

\begin{tabular}{lll}
\hline & Responses & \\
\cline { 2 - 3 } & $\mathrm{n}$ & $\%$ \\
\hline Medscape & 237 & $79.0 \%$ \\
Gray's Anatomy & 190 & $63.3 \%$ \\
UpToDate & 194 & $64.7 \%$ \\
Pubmed Mobile & 145 & $48.3 \%$ \\
Oxford Medical Dictionary & 223 & $74.3 \%$ \\
Epocrates & 188 & $62.7 \%$ \\
Oxford Clinical Handbooks & 178 & $59.3 \%$ \\
Student BMJ & 182 & $60.7 \%$ \\
Skyscape & 208 & $69.3 \%$ \\
Differential Diagnosis BMJ & 114 & $38.0 \%$ \\
iPharmacy & 154 & $51.3 \%$ \\
Prognosis & 171 & $57.0 \%$ \\
Pocket Lab Values & 90 & $30.0 \%$ \\
ECG Guide & 92 & $30.7 \%$ \\
iStethoscope & 88 & $29.3 \%$ \\
Micromedex & 84 & $28.0 \%$ \\
Eponyms & 69 & $23.0 \%$ \\
NEJM & 39 & $13.0 \%$ \\
Instant ECG & 36 & $12.0 \%$ \\
Diagnosaurus DDx & $36.0 \%$ \\
MedCalc & & $14.0 \%$ \\
\hline
\end{tabular}

installed medical apps. The finding is supported by Rikesh et al., who found that juniors frequently use the medical apps as compared to their seniors and are able to access more information in the medical apps [30]. Medical apps were also accessed by several practitioners for various purposes. The finding is also supported by Rikesh et al. [30], who reported that medical apps are used to access more information related to medicine by health care practitioners.

Our study had several limitations. First, our sample size was relatively small and a study that examines medical app use in a larger group of Saudi Arabian medical practitioners is needed to confirm our findings. Still, our results are in agreement with those found in other regions and provide preliminary information on the benefits of medical apps in Saudi Arabia. Second, our study only examined provider perception of medical apps. Future studies examining regional patient use and perception of medical apps are needed to more completely examine how medical apps impact healthcare. Third, we did not examine differences between urban and rural locations. Because medical apps make care more accessible to patients in rural locations, it would be interesting to examine similarities in and differences between medical app use in urban and rural healthcare locations. Fourth, 
since temporality of association is a strong criterion for causality, cross-sectional studies cannot prove causality but help to generate causal hypotheses. Lastly, our study did not examine potentially negative impacts of medical app use. Concerns regarding patient safety and confidentiality have been raised $[2,31]$ and require further investigation.

\section{Conclusion}

In conclusion, the use of medical apps seems to be most beneficial to healthcare practitioners in Saudi Arabia because they make up-to-date medical information more readily available. This information may have a direct impact on patient care, largely because of influences on confirming/assigning diagnoses and determining treatment options. Future studies are needed to better quantify the impact of medical app use on patient care (e.g., correct diagnosis rates, time from diagnosis to treatment, and patient care costs). Studies that examine the impact of medical apps on the patient side in Saudi Arabia are also needed.

\section{Additional file}

Additional file 1: Study Questionnaire. (DOCX $21 \mathrm{~kb}$ )

\section{Acknowledgments}

The author wishes to thank Dr. Abdurrahman Al Theyab (Dean of the College of Medicine and Supervisor of the University Hospital of Prince Sattam bin Abdul-Aziz University) for assistance and expert advice pertaining to this study.

\section{Funding}

The Deanship of Scientific Research at Prince Sattam bin Abdulaziz University with the ethical no- 2017/03/3361 funded the study.

\section{Availability of data and materials}

Data are available upon request from the author.

\section{Authors' contributions}

This work was performed by Dr. Sameer Al-Ghamdi, who designed the study, collected and processed questionnaires, created the manuscript, and approved the final version of the manuscript.

\section{Ethics approval and consent to participate}

The study was reviewed and approved by the Deanship of Scientific Research at Prince Sattam bin Abdulaziz University with the ethical no- 2017/ 03/3361 and written informed consent was obtained from participants.

\section{Competing interests}

The author declares that he has no competing interests.

\section{Publisher's Note}

Springer Nature remains neutral with regard to jurisdictional claims in published maps and institutional affiliations.

Received: 2 October 2017 Accepted: 16 April 2018 Published online: 20 April 2018

\section{References}

1. Mosa ASM, Yoo I, Sheets L. A systematic review of healthcare applications for smartphones. BMC Med Inform Dec Mak. 2012;12:67.
2. Thomairy NA, Mummaneni M, Alsalamah S, et al. Use of smartphones in hospitals. Health Care Manag (Frederick). 2015;34:297-307.

3. Ventola MS. Mobil devices and apps for health care professionals: uses and benefits. Pharm Ther. 2014:39:356-64.

4. Ozdalga E, Ozdalga A, Ahuja N. The smartphone in medicine: a review of current and potential use among physicians and students. J Med Internet Res. 2012;14(5):e128.

5. Kiser K. 25 ways to use your smartphone. Physicians share their favorite uses and apps. Minn Med. 2011;94(4):22-9.

6. Mickan S, Tilson JK, Atherton $\mathrm{H}$, et al. Evidence of effectiveness of health care professionals using handheld computers; a scoping review of systematic reviews. J Med Internet Res. 2013;15(10):e212.

7. Nogueira RG, Silva GS, Lima FO, et al. The FAST-ED app: a smartphone platform for the field triage of patients with stroke. Stroke. 2017:48:1278-84.

8. Divali P, Camosso-Stefinovic J, Baker R. Use of personal digital assistants in clinical decision making by health care professionals: a systematic review. Health Informatics J. 2013;19:16-28.

9. Payne KB, Wharrad H, Watts K. Smartphone and medical related app use among medical students and junior doctors in the United Kingdom (UK): a regional survey. BMC Med Inform Dec Mak. 2012;12:121.

10. West DM. Improving health care through mobile medical devices and sensors. Center for Technology Innovation at Brookings October. 2013;

11. Boulos MNK, Brewer AC, Karimkhani C, et al. Mobile medical and health apps: state of the art, concerns, regulatory control and certification. Online J Public Health Inform. 2014;5:229.

12. O'Neill S, Brady RR. Clinical involvement and transparency in medical apps; not all apps are equal. Color Dis. 2013;15:122.

13. Visvanathan A, Hamilton A, Brady RR. Smartphone apps in microbiology-is better regulation required? Clin Microbiol Infect. 2012;18:E218-20.

14. Ferrero NA, Morrell DS, Burkhart CN. Skin scan: a demonstration of the need for FDA regulation of medical apps on iPhone. J Am Acad Dermatol. 2013; 68:515-6.

15. Wolf JA, Moreau J, Akilov O, et al. Diagnostic inaccuracy of smartphone applications for melanoma detection. JAMA Dermatol. 2013;149:422-6.

16. Robson Y, Blackford S, Roberts D. Caution in melanoma risk analysis with smartphone application technology. Br J Dermatol. 2012;167:703-4.

17. Subhi Y, Bube SH, Rolskov Bojsen S, et al. Expert involvement and adherence to medical evidence in medical mobile phone apps: a systematic review. JMIR Mhealth Uhealth. 2015;3:e79.

18. Kamel Boulos MN. Social media and mobile health (chapter 13, under part B: taking action to create and strengthen health literacy-friendly settings). In: Kickbusch I, Pelikan J, Apfel F, Tsouros A, editors. THE SOLID FACTS - health literacy. Copenhagen: World Health Organization Regional Office for Europe; 2013. p. 63-7.

19. Murfin M. Know your apps: an evidence-based approach to the evaluation of mobile clinical applications. J Physician Assist Educ. 2013;24:38-40.

20. Statistics Book. Ministry of Health - Kingdom of Saudi Arabia. 2015. Available at: http://www.moh.gov.sa/en/Ministry/Statistics/book/Pages/ default.aspx. Accessed 19 Apr 2018.

21. Prgomet M, Georgiou A, Westbrook J. The impact of mobile handheld technology on hospital physicians' work practices and patient care: a systematic review. J Am Med Inform Assoc. 2009;16:792-801.

22. Patel RK, Sayers AE, Patrick NL, et al. A UK perspective on smartphone use amongst doctors within the surgical profession. Ann Med Surg (Lond). 2015; 4:107-12.

23. O'Neill KM, Holmer H, Greenberg SL, Meara JG. Applying surgical apps: smartphone and tablet apps prove useful in clinical practice. Bull Am Coll Surg. 2013;98:10-8.

24. Franko Ol, Tirrell TF. Smartphone app use among medical providers in ACGME training programs. J Med Syst. 2012;36:3135-9.

25. Katz-Sidlow RJ, Lindenbaum Y, Sidlow R. Residents' attitudes toward a smartphone policy for inpatient attending rounds. J Hosp Med. 2013;8: $541-2$.

26. Kim B, Ball M. Mobile use in medicine: taking a cue from specialized resources and devices. Ref Lib. 2010;52:57-67.

27. Buchholtz A, Perry B, et al. Smartphone use and perceptions among medical students and practicing physicians. J Mob Technol Med. 2016;5: $27-32$.

28. Jamal A, Temsah M-H, Khan SA, et al. Mobile phone use among medical residents: a cross-sectional multicenter survey in Saudi Arabia. JMIR Mhealth Uhealth. 2016;4:e61. 
30. Patel RK, Sayers AE, Patrick NL, Hughes K, Armitage J, Hunter IA. UK perspective on smartphone use amongst doctors within the surgical profession. Ann Med Surg. 2015;4:107-12.

29. Lewis TL, Wyatt JC. mHealth and mobile medical apps: a framework to assess risk and promote safer use. J Med Internet Res. 2014;16:e210.

31. Buijink AW, Visser BJ, Marshall L. Medical apps for smartphones: lack of evidence undermines quality and safety. Evid Based Med. 2013;18:90-2.

Ready to submit your research? Choose BMC and benefit from:

- fast, convenient online submission

- thorough peer review by experienced researchers in your field

- rapid publication on acceptance

- support for research data, including large and complex data types

- gold Open Access which fosters wider collaboration and increased citations

- maximum visibility for your research: over $100 \mathrm{M}$ website views per year 